\title{
Implementing the Riparian Particulate Model to assess the impact of watercourse project in the Myponga River Catchment
}

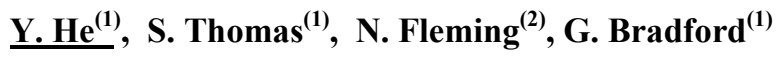 \\ ${ }^{(1)}$ Environment Protection Authority, South Australia \\ ${ }^{(2)}$ South Australian Research and Development Institute
}

Email: ying.he@epa.sa.gov.au

\begin{abstract}
Riparian buffers are vegetated strips of land which separate surface waters from areas which contribute water and constituent runoff. They play an important environmental function of reducing pollutant inputs to streams. In the Myponga River Catchment of the Mount Lofty Ranges in South Australia, considerable work was undertaken between 2000 and 2007 to construct and revegetate riparian buffer zones in order to mitigate pollutant loads to streams. This paper describes how the Riparian Particulate Model (RPM) (Newham et al, 2005) can be used to investigate the potential benefits of the work in improving water quality in the catchment.

The RPM model is a simple conceptual model of particulate trapping in riparian buffer zones. It simulates the particulate trapping capacity of riparian buffers through settling, infiltration and adhesion. The RPM runs at a daily time interval and operates as a filter module within the Source Catchments modelling framework (eWater CRC, Australian). Source Catchments is a node-link catchment scale model for simulating hydrology and constituents impact in catchments.
\end{abstract}

This paper reports development and application of the RPM in the Myponga Catchment. Development of the RPM in Source Catchments involves three stages: runoff generation, constituent generation and filtering. More specifically;

- building the rainfall-runoff model using SIMHYD

- building the constituent generation model using event mean (stormflow) concentration and dry weather (baseflow) concentration. These are used to calculate sediment and nutrient loads from flow of streams in the Myponga River Catchment

- developing and implementing the RPM model to simulate the trapping of coarse and fine particulate in riparian buffer zones.

The Myponga RPM was applied to assess the likely impacts of riparian buffer establishment over the period 2000 to 2007. The model predicted that the amount of fencing and revegetation of the watercourses undertaken in the catchment (around 10\%) would have reduced the overall sediment load by approximately $12 \%$. In certain areas of the catchment where more extensive works were undertaken, sediment loads would have been reduced by up to 54\%. This indicated that the Myponga Watercourse Restoration Project had made improvements to water quality in the catchment.

This paper reports semi-quantitative predictions of potential particulate trapping by grass riparian buffers at a catchment scale. These predictions provide valuable information to the SA EPA and the AMLRNRM (Adelaide and Mount Lofty Ranges Natural Resources Management Board) in their future riparian buffer zone establishment and restoration projects. Furthermore, development of riparian filtering models such as the RPM can be beneficial for government agencies to assess the benefits of on-ground work and to target remedial action.

Keywords: catchment modelling; riparian buffer; Source Catchments; riparian particulate model 
He et al., Implementing the Riparian Particulate Model to Assess the Impact of Watercourse Project in the Myponga River Catchment

\section{INTRODUCTION}

During 1998 the SA EPA surveyed the condition of watercourses within the Myponga Reservoir catchment. This showed that the greatest risk to water quality in the area was unrestricted livestock access to watercourses, and lack of riparian vegetation. As a result, the EPA undertook the Myponga Watercourse Restoration Project (the Project) from 2000 until 2007. This project aimed to fence watercourses, install stock crossings, revegetate riparian buffer zones, implement weed and erosion control measures, and install offstream watering points for livestock.

The EPA carried out on-ground surveys of restored riparian buffers on each property in 2005 and 2007. The survey enabled the water quality impacts of the on-ground works, implemented over the past seven years, to be investigated. The Riparian Particulate Model (RPM) was chosen to evaluate the effects of the restored riparian buffers on water quality because of its measurable parameter values, and its ability to be incorporated within a large-scale catchment model such as Source Catchments.

This paper briefly describes the RPM and then illustrates the development of the Myponga RPM. The application of the model is then demonstrated in two scenarios; the existing case model and the futuredevelopment model. The existing case model was created based on current riparian fencing; thus it represents current riparian buffer trapping capability. The future-development model assumes the same catchment and hydrological behaviour as the existing case model, but differs in that it assesses the effects of increasing the amount of future riparian buffer zone construction and restoration. The model results have indicated that continued riparian buffer establishment and restoration can greatly improve water quality.

\section{THE MYPONGA RIVER CATCHMENT}

The catchment is located in the southern section of the Mount Lofty Ranges (MLR) watershed and is approximately $120 \mathrm{~km}^{2}$ in area. The catchment consists predominantly of rural land, but also contains the township of Myponga. The Myponga River is the largest contributor of sediment and nutrient loadings to the Myponga Reservoir, which supplies mains water to over 50,000 people on the central and southern Fleurieu Peninsula. Land management practices (including riparian management) are critical for the control of sediment and nutrient pollution.

There are five locally recognized sub-catchments within the catchment. These are Gauging Station, Tiers, Myponga, Blockers Road and Pages Flat, ranging in size from 6 to $40 \mathrm{~km}^{2}$ (see Figure 1). This catchment has a large central floodplain area with low longitudinal slopes, so particles are slow moving and drop out of the overland water flow more quickly than some other catchments in the MLR watershed.

There are approximately $260 \mathrm{kms}$ of watercourses in the Myponga catchment of which the Myponga River is the largest. The watercourse restoration project restored and established riparian buffer zones along over $23 \mathrm{kms}$ of the waterways prior to entering the reservoir in the catchment from 2000 until 2007. Figure 1 illustrates the location of the riparian restoration work within the five subcatchments. It can be seen that the majority of the riparian restoration work has been carried out in the Pages Flat sub-catchment.

There has been no new survey data since the EPA transferred the Project to the Adelaide and Mount Lofty Ranges Natural Resources Management Board (AMLR NRM Board) in 2008. Therefore, this paper investigates only the water quality impacts of the riparian restoration work up to 2007 in the catchment.

\section{MODELING FRAMEWORK}

The catchment-scale application of the RPM has been designed to be implemented within Source Catchments (previously known E2/WaterCAST) developed by eWater and is available online at 
http://www.toolkit.net.au/tools/source-catchments. Source Catchments builds upon the flexible modelling framework that evolved from E2 which allows different models to be chosen to best suit a particular problem. The main model structure of Source Catchments is 'node-link', where sub-catchments feed water and materials into nodes, from where they are routed along links. The smallest spatial unit is a sub-catchment. A sub-catchment can be further divided into Functional Units (FUs). FUs are the most fundamental representation of spatial behaviour within Source Catchments. The Myponga Source Catchments model has 8 FUs based on land-uses derived from 2008 landuse data supplied by the Department of Environment and Natural Resources. Each FU can have associated with it a runoff generation model, a constituent generation model and a filter model (Argent et al. 2005). The former two components predict daily time series of overland flow and constituent loads. The filtering component is of special interest in this report. The RPM model operates as a filter module in Source Catchments to reduce sediments from surface flow prior to entering streams. This section will briefly introduce the development and calibration of first two basic model components. Following this, the section will focus on the RPM model development for the Myponga catchment.

\subsection{Rainfall-runoff model}

A 'bucket-style' rainfall-runoff model, SIMHYD model, based on Chiew (2002), was used in the Myponga Source Catchments model. It is a daily conceptual model that estimates stream flow from daily rainfall and areal evapotranspiration. In the Myponga model, climate data was obtained from the SILO in ASCII grid format. The SIMHYD model was calibrated using PEST, a model-independent parameter estimation program (Doherty, 2010). Parameterisation of the model was conducted for up to three separate land uses including: forest, grazing and urban.

PEST usually uses a three component objective function (monthly volumes, daily flows and flow duration curves) to drive the parameter optimization. In this project, the objective function was weighted approximately $60 \%$ daily flows, $30 \%$ monthly volumes and $10 \%$ flow duration curves. The Nash Sutcliffe Coefficient (NS) was used as the primary model performance indicator in addition to volumetric error.

Flow data from the Myponga gauging station A502502 was used for the calibration process over the period of 1978 to 2008; good agreement (daily $\mathrm{NS}=0.76$; monthly NS $=0.90$ ) was obtained between the predicted and observed flow values. Figure 2 shows the flow calibration results on a daily basis.

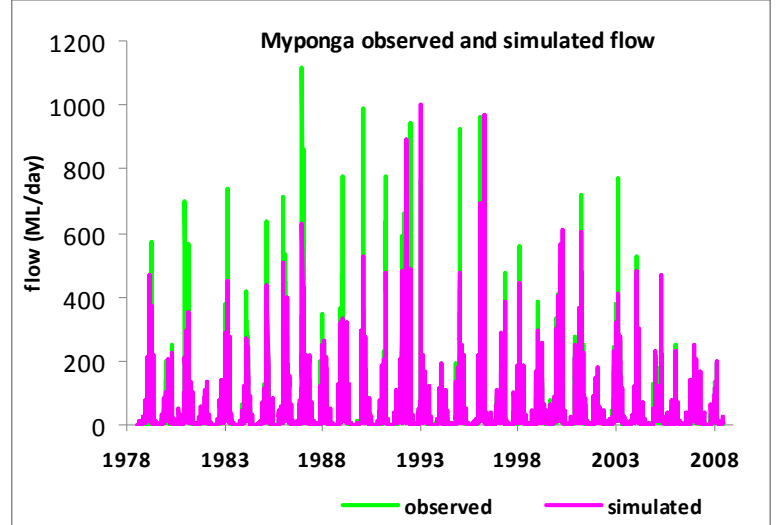

Figure 2. Observed and predicted daily flows for the Myponga catchment

\subsection{Constituent generation model}

An event mean concentration/dry weather concentration (EMC/DWC) approach was applied to simulate water quality in the Myponga model. The EMC/DWC values were calculated using local water quality data collected in the MLR watershed from 21 water quality sites monitored up to 20 years. The development of the EMC/DWC dataset is detailed in Fleming, et al. (2010). The pollutant concentrations for the total suspended solids (TSS) values for 8 landuse categories were used in the model.

\section{RIPARIAN PARTICULATE MODEL (RPM)}

\subsection{Model structure}

An important role of riparian buffer zones is to reduce pollutant inputs to streams. The RPM is specifically used to simulate the trapping capability of riparian buffer zones through three main mechanisms that of settling, infiltration and adhesion (Newham, et al. 2005). The trapping capacity of riparian buffer zones depends on the quantity of particulates it can store. The RPM sub-divides the total particulate load into two size classes (coarse and fine). As a result, the RPM has two trapping storages, one for coarse material and one for fine material (Newham et al. 2005). 
In the RPM, coarse particulates are assumed to be trapped via settling, while fine particulates can be trapped through infiltration into a fixed volume corresponding to soil macropores. Newham et al (2007) have highlighted two critical factors influencing the capacity of the coarse storage, that is, the storage volume and the density of particulates that can be packed in it. The storage volume depends on the length and width of the riparian buffer zone, the effective height to which particulates may accumulate, and the ground slope. The trapping ability of fine sediment storage depends on soil macroporosity and depth of unsaturated porous soil layer.

In the catchment-scale application of the RPM, there are two approaches to modelling coarse and fine particulates; one applies different EMC/DWC values for coarse and fine particulates separately, and the other uses the proportion of coarse particulates entering streams. The difference between the two approaches is that the second approach can not generate output loads for coarse and fine particulates separately. As a result, the first one is highly recommended (Newham et al, 2005). However the second approach was applied in the model, because it is not able to derive the EMC/DWC values for coarse and fine particulates separately in the absence of detailed water quality sampling data.

\subsection{Input data}

The RPM model has considerable data required to be collected from the field, in addition to the Source Catchments input data. This includes soils, vegetation cover, riparian buffer zone sizes, and hydrologic characteristics.

For the development of the Myponga RPM, data was collected from over 20 sample sites throughout the project area. These sample sites covered a range of vegetation types and densities. Vegetation cover was classified into three groups - trees, shrubs, and a third group including grasses, reeds and rushes. However, due to the RPM model structure it was necessary to concentrate on ground cover (grasses) only. The average vegetation growth rate in the project area was estimated, based on local climatic conditions and growth rates of different species.

Soils data was derived from the 2006 Soil Mapping GIS data supplied by the Department for Water (DFW). In the Myponga catchment area there are three main soil groups; 'Loam over brown clay', 'Thick sand over clay', and 'Acidic loam over clay and rock' with soil depths (depth of the $A$-soil horizon) varying from $33 \mathrm{~cm}$ to $66 \mathrm{~cm}$. Soils in the restoration areas are mainly loams and sands which have particle sizes ranging from $0.0002 \mathrm{~mm}$ to $2 \mathrm{~mm}$. Due to lack of in-situ soil sample data, several model parameters such as coarse particulate percentage were estimated based on the DFW soil mapping data and local knowledge.

There were varying widths of riparian buffer zones constructed and restored during the restoration project. The current RPM model only supports up to four different buffer widths, so the restored buffer zones were grouped into 4 different classifications; that of $5 \mathrm{~m}, 15 \mathrm{~m}, 30 \mathrm{~m}$ and $50 \mathrm{~m}$ width on either side of the stream channels. This information plus the location of each riparian buffer zone was used to generate a buffer map to show size and location of buffer restoration in the stream network.

\subsection{Pre-processor}

A RPM pre-processor has been developed for Source Catchments and is specifically designed to ease the input of spatial data for the model. This pre-processor requires a digital elevation model (DEM), land-use map and a map of riparian buffer area. Stream threshold is also required for further breaking down subcatchments into sub-sub-catchments. The pre-processor automatically generates the length of buffered streams and the average buffer slopes for different buffer types for each particular land-use (FU) where a riparian buffer exists.

For the current project, a DEM with a $25 \mathrm{~m}$ cell size was used to generate the sub-catchments and stream network. A stream threshold of $2.5 \mathrm{~km}^{2}$ was chosen for building the RPM model in Source Catchments. This gave a total of 32 sub-catchments generated in the Myponga catchment. For the RPM pre-processor, the stream threshold was set at $0.25 \mathrm{~km}^{2}$ as the sub-catchments needed to be further divided into sub-subcatchments for riparian analysis in the RPM.

\subsection{Results and discussions}

The current Myponga model has three scenarios including base (pass-through) scenario, existing scenario, and future-development scenario. The pass-through scenario was constructed to simulate sediment loads from 2000 to 2007, assuming that surface water flowed to streams without any riparian buffer zones. The existing scenario was developed to represent the riparian buffer zone restoration works implemented over the 
He et al., Implementing the Riparian Particulate Model to Assess the Impact of Watercourse Project in the Myponga River Catchment

past seven years. The future-development scenario assumed the same catchment and hydrological behaviour as the existing case model but differed in that it included the likely riparian buffer zone construction and restoration in the future. This enabled comparisons to be made between these scenarios.

As discussed previously, the RPM acts to filter sediments from surface flows before entering streams. The primary outputs from the Myponga RPM Model are a daily time series of flow and TSS, and an estimate of overall riparian buffer zone trapping efficiency by comparing different scenarios.

\section{Existing scenario}

Annual average loads of TSS were calculated from eight land use activities within the 32 Source Catchments sub-catchments for the period $2000-2007$ during the riparian restoration work. Figure 2 shows the TSS percentage reduction within the subcatchments. These values are the difference between the pass-through scenario (no riparian buffers) and the existing scenario (riparian restoration work undertaken to 2007), with around $10 \%$ of stream bank rehabilitated.

As shown in Figure 3, the TSS trapping capabilities varied among sub-catchments. Some sub-catchments, such as numbers 16, 17 and 30, had more than 30\% TSS reduction. In the case of sub-catchment 17 (SC\#17) there was about 55\% sediment reduction. This is because these subcatchments had the highest proportion of stream buffer fencing undertaken in the area. This also demonstrated that the capacity of sub-catchments to reduce sediments is strongly related to the proportion of total

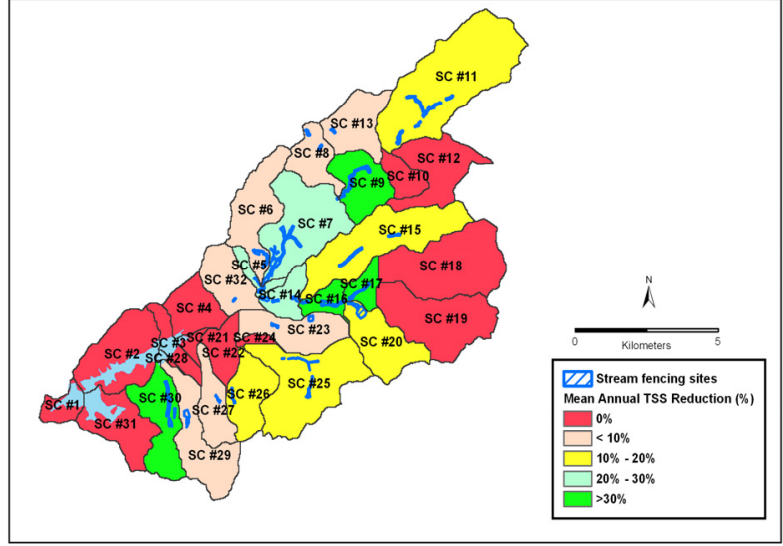

Figure 3. Average annual TSS percentage reduction for the period $2000-2007$ on sub-catchments base stream network length which had riparian restoration undertaken, as more riparian buffer zones meant larger storage trapping capacities.

To further compare the TSS trapping efficiency between five locally recognized sub-catchments, the annual average loads of TSS from 32 sub-catchments were aggregated into these 5 sub-catchments. Figure 4 presents the annual average reduction between the pass-through scenario and the existing scenario in five sub-catchments.

Table 1 further details the TSS reductions per subcatchment in relation to the proportion of stream length that has had riparian restoration work carried out during the project. It can be seen that the Pages Flat sub-catchment has the highest reduction in TSS (shown in Figure 4). This is probably linked to the highest percentage of stream length with restored riparian buffers. The trapping efficiency from the Gauging Station sub-catchment is quite small, because less than $1 \%$ of the stream length has been restored with riparian buffer zones.

According to the model results, the annual average TSS percentage reduction before entering the Myponga reservoir for the whole catchment is approximately $12 \%$ for the period $2000-2007$. This can be considered very positive in the light of such a small percentage (10\%) of waterways

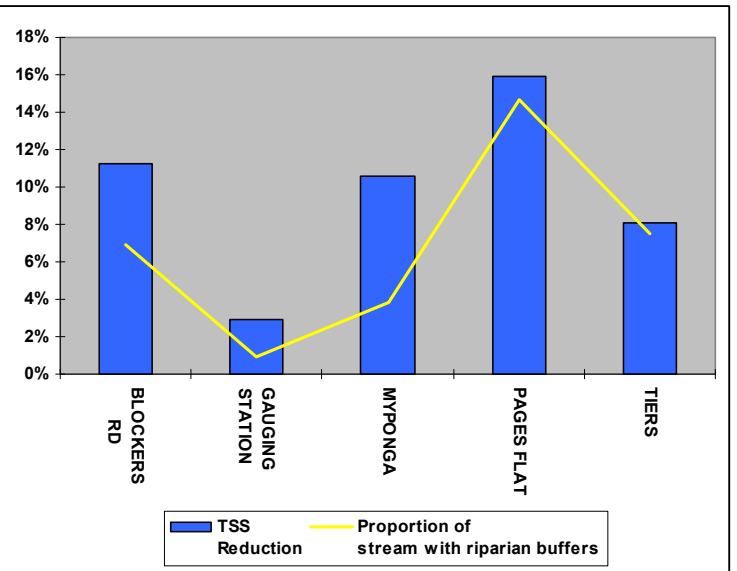

Figure 4. Annual average percentage reduction of TSS for 5 subcatchments between 2000 and 2007 
He et al., Implementing the Riparian Particulate Model to Assess the Impact of Watercourse Project in the Myponga River Catchment

Table 1. Characteristics of current riparian buffers and their trapping capabilities in the sub-catchments

\begin{tabular}{|l|c|c|c|c|c|}
\hline Sub Catchment Name & $\begin{array}{c}\text { Stream } \\
\text { length(m) }\end{array}$ & $\begin{array}{c}\text { Fenced } \\
\text { stream length (m) }\end{array}$ & $\begin{array}{c}\text { Proportion of } \\
\text { fencing }\end{array}$ & $\begin{array}{c}\text { Average } \\
\text { buffer width (m) }\end{array}$ & $\begin{array}{c}\text { TSS } \\
\text { annual average } \\
\text { reduction }\end{array}$ \\
\hline BLOCKERS RD & 57600 & 4005 & $7.0 \%$ & 24.8 & $11 \%$ \\
\hline GAUGING STATION & 15092 & 138 & $0.9 \%$ & 5.0 & $3 \%$ \\
\hline MYPONGA & 67576 & 2589 & $3.8 \%$ & 17.1 & $11 \%$ \\
\hline PAGES FLAT & 79859 & 11729 & $14.7 \%$ & 22.2 & $16 \%$ \\
\hline TIERS & 45399 & 3398 & $7.5 \%$ & 22.9 & $8 \%$ \\
\hline Total: & 265525 & 21858 & $8.2 \%$ & 18.4 & $12 \%$ \\
\hline
\end{tabular}

\section{Future-development scenario}

Reclaiming land for development of riparian management zones is thought to improve the water quality outcomes associated with these management actions. The prevailing conditions and the size, type and makeup of the buffer zones dictate the extent of the benefits. The future-development scenario was developed to understand and compare the improvements, or otherwise, in TSS removal by increasing riparian buffer zone size. These investigations included examining the influence of increasing buffer zone widths and lengths. For example, Sub-catchments 11 and 15 were modelled based on hypothetically constructing new riparian buffer zones, thus, adding $3 \mathrm{~km}$ of buffer length and increasing buffer width to $15 \mathrm{~m}$. Table 2 shows the characteristics of both current and new riparian buffer zones and their estimated trapping performance.

Table 2. Modeled riparian buffer performances of existing and future-development scenario

\begin{tabular}{|c|c|c|c|c||c|c|c|}
\hline SC & $\begin{array}{c}\text { Stream } \\
\text { length } \\
\mathbf{( m )}\end{array}$ & $\begin{array}{c}\text { Current } \\
\text { Buffered } \\
\text { stream } \\
\text { length (m) }\end{array}$ & $\begin{array}{c}\text { Current stream } \\
\text { buffered } \\
\text { percentage }\end{array}$ & $\begin{array}{c}\text { Current } \\
\text { riparian } \\
\text { trapping } \\
\text { efficiency }\end{array}$ & $\begin{array}{c}\text { New } \\
\text { buffered } \\
\text { stream } \\
\text { length (m) }\end{array}$ & $\begin{array}{c}\text { New stream } \\
\text { buffered } \\
\text { percentage }\end{array}$ & $\begin{array}{c}\text { New riparian } \\
\text { trapping } \\
\text { efficiency }\end{array}$ \\
\hline $\mathbf{1 1}$ & $\mathbf{2 2 5 9 1}$ & 3261 & $14.4 \%$ & $16 \%$ & 6682 & $30 \%$ & $33 \%$ \\
\hline $\mathbf{1 5}$ & $\mathbf{1 0 2 9 0}$ & 1495 & $14.5 \%$ & $14 \%$ & 4601 & $45 \%$ & $42 \%$ \\
\hline
\end{tabular}

As illustrated in Table 2, the modelled trapping efficiencies for Sub-catchments 11 and 15 improved by an additional $18 \%$ and $28 \%$ respectively as the stream buffer zone percentage increased by $15 \%$ and $30 \%$. These predicted results clearly show that significant reductions in sediment export can be achieved by increasing the amount of riparian buffer zones within the catchment. Moreover, the interrogation of the modelled results demonstrated this significant difference. Consequently, considerable riparian buffer zone establishment and restoration needs to be continued in order to improve water quality in the Myponga catchment.

\section{Limitations}

It is important to note that the Myponga RPM is only a decision tool and does not give the answer to the actual water quality improvements. As mentioned by Newham et al (2005), the RPM provides only semiquantitative predictions about the likely effectiveness of riparian grass buffers, based on assumptions made in developing the model.

Data availability is the main limitation for the Myponga RPM. Although most model parameters are measurable, several model parameters need to be estimated based on local knowledge. Furthermore, a few input data requirements were not straightforward due to the need for in-situ experiments, such as coarse and fine particulates density. It is always a challenging task to obtain experimental data.

The sensitivity of the Myponga RPM predictions to variations in model parameters, such as effective vegetation height, daily growth rate and buffer size, has been investigated. However, except for buffer size, the other parameters have shown very low sensitivity, which is different from the sensitivity results undertaken by Newham et al. (2005). This could be due to the small proportion of waterways with restored 
He et al., Implementing the Riparian Particulate Model to Assess the Impact of Watercourse Project in the Myponga River Catchment

riparian buffers in the catchment. Thus, the Myponga RPM may under-estimate the trapping capabilities of riparian buffers in the catchment. Further testing of the model is required for more detailed predictions and results.

While the catchment-scale RPM model has proven robust, a simplified RPM model is needed for catchment managers. The current 'filter' RPM model of Source Catchments is not easy to build, especially for large catchments. Scenario testing is also difficult to implement, even for a simple question such as "what additional sediment loads can be trapped by increasing riparian buffer zones by $25 \%$ in a particular catchment'.

\section{CONCLUSIONS}

The Myponga RPM has been applied to assess the likely effects of riparian buffer establishment in the Myponga catchment for the period 2000 to 2007. The model predicted that when compared to the passthrough scenario (without any buffer zones), an annual average of approximately $12 \%$ of incoming sediments would be trapped from surface flows prior to their entry into the Myponga reservoir, as a result of modifying $10 \%$ of waterway length. This indicates that the Myponga Watercourse Restoration Project made improvements to the water quality in the catchment.

In addition, the future-development scenario has shown that the relative reduction in TSS is strongly related to the proportion of stream length with restored riparian buffer zones. This finding implies that a significant improvement of water quality would be achieved if more of the waterways are restored and established with riparian buffer zones. However, it is unclear at what point the relative reduction in TSS would begin to respond less to the increases in buffer size. Moreover, the model has shown that it can provide valuable input into the decision making process regarding prioritisation and design specifications of new buffer zones.

Further development of the Myponga RPM model would incorporate the EMC/DWC values for coarse and fine particulates separately together with targeted monitoring to validate the relative reductions in TSS. This would enable assessment of the capabilities of riparian buffers in trapping coarse and fine particulates individually. This, in turn, would help catchment managers better understand the trapping mechanisms of coarse and fine particulates for the planning of riparian buffer establishment and protection in the Myponga catchment.

In summary, this paper has provided semi-quantitative predictions at a catchment scale of potential particulate trapping by grass riparian buffers. The predictions will provide valuable information to the SA EPA and the AMLRNRM in their future riparian buffer zone establishment and restoration projects. Furthermore, development of riparian filtering models such as the RPM can be beneficial for government agencies to assess the benefits of on-ground work programs and to target remedial action.

\section{ACKNOWLEDGEMENT}

The authors would like to thank Lachlan Newham and Tony Weber for their valuable suggestions during the process of model development. Special thanks go to the staff of Water Quality Branch at EPA for the assistance of data collection. It is much appreciated for the support of eWater CRC (particularly Lydia Cetin and David Waters) in the implementation of RPM with Source Catchments.

\section{REFERENCES}

Argent, R., Podge, R. G., Grayson, R., and Fowler, K. (2005). E2 Catchment modelling software - User Guide. Corporative Research Centre for Catchment Hydrology.

Doherty, J. (2010), PEST Model Independent Parameter Estimation User Manual: $5^{\text {th }}$ Edition. Watermark Numerical Computing.

Fleming, N., Cox, J., He, Y. and Thomas, S. (2010), Analysis of Total Suspended Sediment and Total Nutrient Concentration data in the Mount Lofty Ranges to derive Event Mean Concentrations.

Newham, L., Rutherford, K., and Croke, B. (2005), A conceptual model of particulate trapping in riparian buffers. CSIRO Land and Water Technical Report 21/05.

Newham, L, Weber, T.R, Baker-Finch S.C, Post D.A and Rutherford J.C, (2007) Testing and Application of the Riparian Particulate Model. Proceedings MODSIM07. 